of an article similar, yet far inferior in beauty, and utterly without variety; whereas this rock produces not less than ten or twelve distinct kinds." This beautiful stone is still as much neglected as it was in the time of $M$ 'Culloch. If a market were found for it, it might be quarried close to deep water, where vessels might ride and load in safety; and the works would be carried on with the advantage of every facility that the owner, Sir Lewis Campbell, would willingly afford.

During the few short hours that I could devote to a ramble orer Davar, I found the attractions of the porphyritic rocks to be so seductive, that the hammer was much more frequently in use than the gun.-I am, Sir, yours obediently,

EDwrn Brown, F.G.S.

Burton-on-Trent, February 13, 1866.

\title{
GEOLOGY OF THE MOON.
}

\section{To the Editor of the Geological Magazine.}

Sir,--I have no doubt many of your readers will thank you for introducing the subject of the Moon into the Geologica't Magazink. The letter of Mr. Birch on Lunar Glaciers ought to lead to observations and speculations calculated to enlarge our knowledge of the present and past condition of the moon's surface. That glaciers to a limited extent may now exist, and that traces of former glacial action may be discovered on the surface of the moon, does not appear to be a very extravagant assumption. But few astronomers would probably be disposed to concede that all the white parts of the moon are Snow and Ice. The absence of an atmosphere (beyond a possible shallow gaseous envelope) would at first sight appear to be incompatible with a belief in a general glacial condition of the lunar surface. It is however for the photo-selenologists to inquire whether the modern theory of the moon advocated by Professor Hansen and others will afford him any support. This theory implies that the farther or unseen hemisphere of the moon is a comparative depression in which an ocean surmounted by an atmosphere may exist, and in which volcanic fires have not yet become exhansted-that the side of the moon turned towards us is a vast hemispherical mountainsystem, rising above the lunar sea-level to a height corresponding to the distance between the Centre of figure and Centre of gravity, or according to some about 30 miles. Is it possible that Vapour from the "ultra-montane" sea may find its way over the border, so as to be converted into snow and ice on the higher lands of the visible hemisphere of the moon? The mere asking of such a question may subject a writer to a charge of presumption, if not of ignorance, in the present state of astronomical discovery.

But there is one subject connected with the Geology, or rather Selenology of the moon, on which one may now venture to make suggestions with less hesitation. The theory above noticed 
implies that the lunar depressions anciently called seas are really deserted ocean-beds. Professor Phillips expressed himself in favour of this doctrine at the late meeting of the British Association. It is, I think, very desirable that the army of observers (including those officially instructed by the "Lunar Committee") now besieging the surface of our satellite, should direct particular attention to seacoast phenomena. Excepting where lines of craters have been converted into an irregular succession of cliffs, the effects of marine denudation can scarcely be mistaken. In the moon as well as in the earth, they may be expected to consist of nearly straight lines of escarpment apparently due to undermining and lateral encroachment-winding lines of cliff apparently scooped out into bays with headlands and semi-circular hollows-level areas under escarpments, either terrace-shaped or graduating into the general level of the neighbouring plain-ridges resembling sand-banks, running across the plains or old sea-beds-isolated rocks, or groups of rocks in the neighbourhood of escarpments and especially of promontories, etc. Among the apparent sea-coast phenomena which ought to be minutely observed, I would venture to mention the following :-

First, the more abrupt coasts of the Mare Imbrium. The great Appenine escarpment is very instructive. It is exceedingly steep and lofty, and has apparently been formed along the strike of the metamorphic (?) rocks of which the mountain-range consists. It has here and there been hollowed out into semicircular coves, whïh have not reached the dimensions of bays. Along a considerable part of its course, it overhangs a level beach terminated by a striking line of rocks resembling a natural break-water. Palus Nebularum and Palus Putredinis are so wonderfully level as to point at once to deposition parallel to a horizontal fluid surface. The Wedgeshaped Valley of the Alps is a cleft (voe ?) nearly 12,000 feet deep. Sinus Iridum is a semicircular bay "level almost as water," with "abrupt and colossal cliffs" and promontories 140 miles apart.

Second, the headlands, bays, and coves of Mare Serenitatis and Mare Tranquilitatis, and the apparent beaches and sand-banks by which their surfaces are varied.

Third, the Mare Crisium, with its smoothly-rounded bays and coves. The Promontorium Agarum resembles many terrestrial headlands. Near the east edge there is a pass with island-like mountains. In this deserted sea-bed I have frequently traced level beaches extending from the bases of the cliffs a considerable distance sea-ward, and then terminating suddenly. Similar beaches or level plateans may be traced in other lunar sea-beds.

The so-called canals or rills, especially Hyginus and Ariadæus, with their tributaries, tunnels, raised banks, etc., deserve to be particularly examined with the view of discovering traces of their being dried-up river channels. ${ }^{1}$ - Yours truly,

D. Mackintosh.

I For information on the Selenography of the above and other regions of the moon, see the Rev. T. W. Webb's Celestial Objects; also articles by the same astronomer in the Intellectual Observer. 